\title{
Devising selection strategy for increase in sesame yield based on variability heritability and genetic advance studies
}

\author{
Mubashir Ahmad Khan ${ }^{1 *}$, Nazakat Nawaz ${ }^{2}$ and Tahira ${ }^{2}$
}

1. Maize Sorghum \& Millet Research Program, Crop Sciences Institute (CSI), National Agricultural Research Institute (NARC), Islamabad, Pakistan

2. Oilseeds Research Program, Crop Sciences Institute (CSI), National Agricultural Research Institute (NARC), Islamabad, Pakistan

*Corresponding author's email:mak1584@hotmail.com

Citation

Mubashir Ahmad Khan, Nazakat Nawaz and Tahira. Devising selection strategy for increase in sesame yield based on variability heritability and genetic advance studies. Pure and Applied Biology. Vol. 11, Issue 1, pp226-231. http://dx.doi.org/10.19045/bspab.2022.110024

\begin{tabular}{llll}
\hline \hline Received: 04/03/2021 & Revised: 18/05/2021 & Accepted: 28/05/2021 & Online First: 04/06/2021 \\
\hline \hline
\end{tabular}

\section{Abstract}

The study on ten sesame entries was conducted during Kharif 2017 and 2018 at National Agricultural Research Centre, Islamabad, Pakistan. The results of two years indicated highly significant differences among the genotypes for all the traits showing presence of high degree of variability which could be utilized for sesame crop improvement. Genotypic and phenotypic coefficients of variation (GCV and PCV) were maximum for seed yield followed by pods and branches per plant. Heritability (broad sense) was high (0.69 to 0.97) for all the traits indicating large proportion of the total variance was because of high genotypic variance due to which influence of environment was less on these traits thus having high heritable variation. There were least differences between GCV and PCV values along with high heritability estimates for all the traits indicating less influence of environment. Hence, direct selection is recommended for the improvement. High values of genetic advance as percent of mean for branches per plant, pods per plant and seed yield showing that yield increase through selection can be achieved up to a level of $12.52 \%, 21.86 \%$ and $23.87 \%$ respectively. Branches per plant, pods per plant and seed yield showed high heritability coupled with high GA\% values, indicating that additive genes control these traits and direct selection based on phenotypic performance would be helpful for the improvement in the sesame crop. Therefore, efforts should be focused on these traits for devising selection strategy for increase in sesame yield on the basis of phenotypic performance.

Keywords: Genetic Advance; Heritability; Pakistan; Sesame; Sesamum indicum L.; Variability

\section{Introduction}

Sesame (Sesamum indicum L.) belongs to family Pedaliaceae. It is one of the oldest oilseed crops. It is mainly cultivated in Asia, Africa, and South America and more than $80 \%$ of the sesame producing area is in the developing countries. Seed is the main purpose for its cultivation. Its oil contents range from $40-60 \%$ and protein content $22 \%$ [1]. Sesame oil is highly stable because of the presence of antioxidants lignans such as sesamin, sesamolin, and sesaminol. These compounds have antioxidant, antiaging, antihypertensive, anticancer, cholesterol 
lowering, and antimutagenic properties [1]. Sudan leads in sesame production with 981,000 tons, followed by Mynamar (768,858 tons), India (746,000 tons), Nigeria (572,761 tons), and Tanzania (561,103 tons) (FAOSTAT, 2018). During 2017-18, sesame was cultivated in Pakistan on 82,700 ha with total production of 35,400 tons and national average yield of $428 \mathrm{~kg} / \mathrm{ha}$ (Agricultural Statistics of Pakistan, 2017-18).

Availability of narrow genetic variability hampers sesame breeders for the development of new and superior crop varieties. The understanding of the genetic variability of available gene pool will help in devising selection strategy for the development of high yielding varietiesfor raisingsesame production. Therefore, the present study was planned for devising selection strategy in sesame breeding for increased yield based on understanding variability, heritability and genetic advance as percent of mean for some quantitative traits.

\section{Materials and Methods}

The experimental materials comprised of ten sesame genotypes sown in randomized complete block design with three replications during Kharif 2017 and 2018 at National Agricultural Research Centre, Islamabad, Pakistan. Each experimental unit consisted of 4 rows of 5 meter length with row spacing of $45 \mathrm{~cm}$. Data were recorded on days to flower initiation, days to flower completion, days to maturity, plant height, number of branches per plant, number of pods per plant and seed yield (kg/ha). The data collected were subjected to Analysis of Variance (ANOVA) and Least Significant Difference (LSD) by Statstix 8.1 software. Follow Singh and Chaudhry [2] to calculate of estimates of genotypic and phenotypic variances (GV and PV). Genotypic and phenotypic coefficients of variation (GCV and PCV) and broad sense heritability $\left(\mathrm{H}_{\mathrm{bs}}\right)$ were computed as Burton [3]. Estimates of heritability high $(>50 \%)$, medium (20-50\%) and low $(<20 \%)$ were calculated as suggested by Stansfield [4]. Genetic advance (GA) at 5\% selection intensity and genetic advance as percent of mean (GA \%) were determined following Johnson et al. [5] formula consequently employed by Allard [6].

\section{Results and Discussion}

Analysis of variance over mean data of 2017 and 2018 indicated highly significant differences among the genotypes for all the traits under study showing presence of high degree of variability in the genotypes which could be utilized for sesame crop improvement. Coefficient of variation (CV\%) for these traits ranged from 0.42 to 4.56\% (Table 1). Jamir et al. [7], Patidar el al. [8], Pavani et al.[1] and Sirisha et al. [9] reported significant differences among genotypes for the traits under study.

The performance of sesame genotypes for yield and agronomic traits over mean data of 2017 and 2018 is given in (Table 2). Days to flowering initiation ranged from 41 days (SG-52 and SG-175) to 44 days (SG-11, SG21, SG-58 and SG-93) with a mean value of 43 days. Only two genotypes (SG-52 and SG175 ) initiated flowering (41 days) earlier than check TS-5 (43 days). The range of days to flower completion 69 days (SG-50, SG-93, SG-174 and SG-175) to 72 days (SG-21 and SG-99) having mean value of 70 days. Two entries (SG-21 and SG-99) had longer days to flowering completion period (72 days) compared tocheck TS-5 (71 days). Days to maturity varies from 99 days (SG-50, SG-52, SG-93 and SG-175) to 104 days (TS-5) showing mean value of 100 days. All the entries matured earlier than check TS-5 ranging from 99 to 101 days.

Plant height ranged from $112 \mathrm{~cm}$ (TS-5) to $123 \mathrm{~cm}$ (SG-11) with mean value of $118 \mathrm{~cm}$. All the entries were taller than check TS-5 $(112 \mathrm{~cm})$ and had a range of 115 to $123 \mathrm{~cm}$. Maximum number of branches per plant (4.1) was recorded in SG-50 and minimum (3.2) in 
SG-99 possessing a mean value of 3.6 branches per plant. SG-50, SG-11, SG-21, SG-52, SG-174 and SG-175 had more branches per plant compared to check TS-5 (3.5) with a range of 3.6 to 4.1 branches per plant. Number of pods per plant varies from 47 (SG-93) to 68 (SG-11) showing a mean value of 56 pods. Four genotypes had more pods per plant viz. SG-11, SG-21, SG-174 and SG-50 with a range of 56 to 68 pods per plant than check TS-5 (55 pods). Seed yield of these ten genotypes had a range of 533 $\mathrm{kg} / \mathrm{ha}$ (TS-5) to $828 \mathrm{~kg} / \mathrm{ha}$ (SG-11) having a mean value of $703 \mathrm{~kg} / \mathrm{ha}$. All the genotypes were better in seed yield compared to check TS-5 (533 kg/ha) and had a range of 606 to $828 \mathrm{~kg} / \mathrm{ha}$.

The values of genotypic and phenotypic coefficients of variation (GCV and PCV), heritability $\left(\mathrm{H}_{\mathrm{bs}}\right)$ and genetic advance as percent of mean $(\mathrm{GA} \%)$ are given in (Table 3). GCV and PCV were found maximum for seed yield followed by pods per plant and branches per plant while minimum for days to maturity. Anbanandan [10] reported high GCV and PCV for branches per plant, pods per plant and seed yield. Jamir et al. [7] reported high GCV and PCV values for branches per plant, pods per plant and seed yield. Pavani et al. [1] reported high GCV and PCV values for branches per plant and pods per plant.

Heritability (broad sense) ranged from 0.69 to 0.97 and was high for all the traits indicating that large proportion of the total variance was because of the high genotypic variance due to which influence of environment was less on these traits thus having high heritable variation. These traits possessing high heritability, consequently, may respond more effectively to phenotypic selection. Anbanandan [10] reported high heritability estimates for branches per plant, pods per plant and seed yield. Pavani et al. [1] reported high heritability values for days to flowering, plant height, branches per plant and pods per plant. Jamir et al. [7] and Sirisha et al. [9] reported high heritability values for days to flowering, days to maturity, branches per plant, pods per plant and seed yield.

Furthermore, it was found that there were fewer differences between GCV and PCV values alongwith high heritability estimates for all the traits in this study. These results indicatedthat there would be less influence of environment on these traits. Hence, direct selection is recommended for the improvement. Anbanandan [10] reported similar results for branches per plant, pods per plant and seed yield. Pavani et al. [1] was of same view for branches per plant and pods per plant. Jamir et al. [7] and Sirisha et al. [9] also reported similar results.

High values of genetic advance as percent of mean were observed in branches per plant, pods per plant and seed yield showing that yield increase through selection can be achieved up to a level of $12.52 \%, 21.86 \%$ and $23.87 \%$ respectively within the tested materials. Jamir et al. [7] reported that sesame crops improvement was possible up to $85 \%$. Pavani et al. [1] reported up to $47 \%$ improvement in the sesame crop. Sirisha et al. [9] reported that improvement in sesame crop was possible up to $74 \%$.

High heritability (broad sense) per se is not an index of high genetic gain. Therefore, it should be accompanied by high GA\% when describing the genetic parameters in any crop as cautioned by Kadir et al. [11]. In present study, branches per plant, pods per plant and seed yield showed high heritability coupled with high GA\% values, indicating that additive genes control these traits and direct selection based on phenotypic performance would be helpful for the improvement in the sesame crop. Jamir et al. [7] reported that branches per plant, pods per plant and seed yield are under the influence of additive genes and improvement is possible through selection based on these traits. Patidar et al. [8] reported that improvement in sesame crop 
is possible through selection based on traits having highly heritability and high genetic advance as per cent of mean. Pavani et al. [1] reported that direct selection based on pods per plant is possible. Sirisha et al. [9] reported that branches per plant, pods per plant and seed yield had high heritability and high genetic advance as percent of mean estimates showing the role of additive gene action for these traits which could be exploited by simple selection.

Table 1. Mean Squares for yield and agronomic traits over mean data of 2017 and 2018

\begin{tabular}{|c|c|c|c|c|c|c|c|c|}
\hline $\begin{array}{c}\text { Source of } \\
\text { variation }\end{array}$ & df & $\begin{array}{c}\text { Days } \\
\text { flower } \\
\text { initiation }\end{array}$ & $\begin{array}{c}\text { Days to } \\
\text { flower } \\
\text { completion }\end{array}$ & $\begin{array}{c}\text { Days to } \\
\text { maturity }\end{array}$ & $\begin{array}{c}\text { Plant } \\
\text { height } \\
\text { (cm) }\end{array}$ & $\begin{array}{c}\text { No. of } \\
\text { branches } \\
\text { per plant }\end{array}$ & $\begin{array}{c}\text { No. of } \\
\text { pods per } \\
\text { plant }\end{array}$ & $\begin{array}{c}\text { Seed } \\
\text { Yield } \\
\text { (kg/ha) }\end{array}$ \\
\hline Replication & 2 & 0.03333 & 0.63333 & 0.7000 & 2.7000 & 0.01233 & 20.833 & 4012.9 \\
\hline Genotypes & 9 & $3.02222^{* *}$ & $4.84815^{* *}$ & $6.4037 * *$ & $30.8148^{* *}$ & $0.16626^{* *}$ & $112.681^{* *}$ & $20374.8^{* *}$ \\
\hline Error & 18 & 0.25556 & 0.33704 & 0.18148 & 8.4037 & 0.0227 & 6.759 & 474.5 \\
\hline CV\% & & 1.17 & 0.82 & 0.42 & 2.46 & 4.18 & 4.56 & 3.10 \\
\hline
\end{tabular}

** = Highly significant at $1 \%$ level of probability

Table 2. Mean performance of sesame genotypes for yield and agronomic traits over mean data of 2017 and 2018

\begin{tabular}{|c|c|c|c|c|c|c|c|}
\hline Genotypes & $\begin{array}{c}\text { Days } \\
\text { flower } \\
\text { initiation }\end{array}$ & $\begin{array}{c}\text { Days to } \\
\text { flower } \\
\text { completion }\end{array}$ & $\begin{array}{c}\text { Days to } \\
\text { maturity }\end{array}$ & $\begin{array}{c}\text { Plant } \\
\text { height } \\
\text { (cm) }\end{array}$ & $\begin{array}{c}\text { No. of } \\
\text { branches } \\
\text { per plant }\end{array}$ & $\begin{array}{c}\text { No. of } \\
\text { pods } \\
\text { per } \\
\text { plant }\end{array}$ & $\begin{array}{c}\text { Seed Yield } \\
\text { (kg/ha) }\end{array}$ \\
\hline SG-11 & 44 & 71 & 101 & 123 & 3.7 & 68 & 828 \\
\hline SG-21 & 44 & 72 & 101 & 122 & 3.7 & 64 & 752 \\
\hline SG-50 & 43 & 69 & 99 & 117 & 4.1 & 56 & 681 \\
\hline SG-52 & 41 & 70 & 99 & 119 & 3.7 & 52 & 606 \\
\hline SG-58 & 44 & 71 & 100 & 118 & 3.4 & 54 & 709 \\
\hline SG-93 & 44 & 69 & 99 & 117 & 3.2 & 47 & 759 \\
\hline SG-99 & 43 & 72 & 100 & 118 & 3.5 & 55 & 736 \\
\hline SG-174 & 43 & 69 & 100 & 115 & 3.6 & 57 & 707 \\
\hline SG-175 & 41 & 69 & 99 & 119 & 3.6 & 51 & 720 \\
\hline TS-5 & 43 & 71 & 104 & 112 & 3.5 & 55 & 533 \\
\hline Mean & $\mathbf{4 3}$ & $\mathbf{7 0}$ & $\mathbf{1 0 0}$ & $\mathbf{1 1 8}$ & $\mathbf{3 . 6}$ & $\mathbf{5 6}$ & $\mathbf{7 0 3}$ \\
\hline Minimum & $\mathbf{4 1}$ & $\mathbf{6 9}$ & $\mathbf{9 9}$ & $\mathbf{1 1 2}$ & $\mathbf{3 . 2}$ & $\mathbf{4 7}$ & $\mathbf{5 3 3}$ \\
\hline Maximum & $\mathbf{4 4}$ & $\mathbf{7 2}$ & $\mathbf{1 0 4}$ & $\mathbf{1 2 3}$ & $\mathbf{4 . 1}$ & $\mathbf{6 8}$ & $\mathbf{8 2 8}$ \\
\hline LSD (5\%) & $\mathbf{0 . 8 7}$ & $\mathbf{0 . 9 9}$ & $\mathbf{0 . 7 3}$ & $\mathbf{4 . 9 7}$ & $\mathbf{0 . 3}$ & $\mathbf{4 . 4 6}$ & $\mathbf{3 7 . 3 7}$ \\
\hline
\end{tabular}


Table 3. Estimates of genetic parameters for yield and agronomic traits in sesame genotypes over mean data of 2017 and 2018

\begin{tabular}{|c|c|c|c|c|c|c|c|}
\hline $\begin{array}{c}\text { Genetic } \\
\text { parameters }\end{array}$ & $\begin{array}{c}\text { Days } \\
\text { flower } \\
\text { initiation }\end{array}$ & $\begin{array}{c}\text { Days to } \\
\text { flower } \\
\text { completion }\end{array}$ & $\begin{array}{c}\text { Days to } \\
\text { maturity }\end{array}$ & $\begin{array}{c}\text { Plant } \\
\text { height } \\
\text { (cm) }\end{array}$ & $\begin{array}{c}\text { No. of } \\
\text { branches } \\
\text { per plant }\end{array}$ & $\begin{array}{c}\text { No. of } \\
\text { pods per } \\
\text { plant }\end{array}$ & $\begin{array}{c}\text { Seed } \\
\text { Yield } \\
\text { (kg/ha) }\end{array}$ \\
\hline $\begin{array}{c}\text { Genotypic } \\
\text { variance } \\
\text { (GV) }\end{array}$ & 0.92 & 1.50 & 2.07 & 7.47 & 0.05 & 35.31 & 6633.43 \\
\hline $\begin{array}{c}\text { Phenotypic } \\
\text { variance (PV) }\end{array}$ & 1.18 & 1.84 & 2.26 & 15.87 & 0.07 & 42.07 & 7107.93 \\
\hline $\begin{array}{c}\text { Genotypic } \\
\text { coefficient of } \\
\text { variation \% } \\
\text { (GCV) }\end{array}$ & 2.23 & 1.75 & 1.44 & 2.32 & 6.08 & 10.61 & 11.59 \\
\hline $\begin{array}{c}\text { Phenotypic } \\
\text { coefficient of } \\
\text { variation \% } \\
\text { (PCV) }\end{array}$ & 2.52 & 1.94 & 1.50 & 3.38 & 7.38 & 11.58 & 11.99 \\
\hline $\begin{array}{c}\text { Heritability } \\
\text { (H(bs) }\end{array}$ & 0.88 & 0.90 & 0.96 & 0.69 & 0.82 & 0.92 & 0.97 \\
\hline $\begin{array}{c}\text { Genetic } \\
\text { advance (GA) }\end{array}$ & 1.98 & 2.53 & 2.97 & 5.63 & 0.45 & 12.24 & 167.78 \\
\hline $\begin{array}{c}\text { Genetic } \\
\text { advance as } \\
\text { percent of } \\
\text { mean (GA\%) }\end{array}$ & 4.60 & 3.61 & 2.97 & 4.77 & 12.52 & 21.86 & 23.87 \\
\hline
\end{tabular}

\section{Conclusion}

Identification of superior genotypes is prerequisite to achieve progress from selection. From the results of this study, it is observed that branches per plant, pods per plant and seed yield are under the control of additive genes as they had high values of heritability coupled with genetic advance as percent of mean, hence, provide a good selection base. Therefore, efforts should be focused on these traits for devising selection strategy for increase in sesame yield on the basis of phenotypic performance.

\section{Authors' contributions}

Conceived and designed the experiments: MA Khan, Performed the experiments: MA Khan, N Nawaz \& Tahira, Analyzed the data: MA Khan, N Nawaz \& Tahira, Contributed materials/ analysis/tools:

Tahira, Wrote the paper: MA Khan

\section{References}

1. Pavani K, Ahamed ML, Ramana JV \& Sirisha ABM (2020). Studies on genetic variability parameters in sesame (Sesamum indicum L.). Inter J of Chem Stud 8(4): 101-104.

2. Singh RK \& Chaudhry VD (1985). Biometrical Methods in Quantitative Genetic Analysis. Klyani Publishers, New Delhi, India. pp.53-54.

3. Burton GW (1952). Quantitative inheritance in grasses. Proc. $6^{\text {th }}$ Int'l. Grassland Cong 1: 277-283.

4. Stansfield WD (1986). Theory and Problems of Genetics. McGraw Hill Book Co. New York, USA. pp. 220-221.

5. Johnson HW, Robinson HF \& Comstock RE (1955). Estimates of genetic and environmental variability in soybean. Agron J 47: 314-318. 
6. Allard RW (1960). Principles of Plant Breeding. John Willey and Sons, Inc., New York USA. pp. 484.

7. Jamir M, Changkija S, \& Chaturvedi HP (2020). Genetic variation in sesame (Sesamum indicum L.) landraces of North East India. $J$ of Pharma and Phytochem9(4): 634-637.

8. Patidar B, Tripathi D, Patidar S, Patidar M, Singh Y \& Kumari G (2020). Genetic variability, heritability and genetic advance studies in sesame (Sesamum indicum L.). $J$ of Pharma and Phytochem9(3): 1679-1683.
9. Sirisha ABM, Banu SKH \& Saritha R (2020). Assessment of genetic variability, heritability in sesame (Sesamum indicum L.). Inter J of Chem Stud 8(4):2262-2264. 10. Anbanandan V (2018). Genetic variability and heritability in sesame (Sesamum indicum L.). Eur $J$ of Biotechnol and Biosci 6(5): 69-70.

11. Kadir M, Biswas BK, Podder P, Alam MS \& Adhikary SK (1996). Genetic parameters, character association and path analysis in sesame. Bang $J$ of Agric Res 21(1): 37-43. 